\title{
Multi Aesthetics in Modern Batik of Hardjonagoro Go Tik Swan
}

\author{
Suyin Pramono Setiawan Sabana Achmad Haldani Destiarmand Acep Iwan Saidi \\ Faculty of Fine Art and Design Institute of Technology Bandung \\ Jl. Ganesha No. 10 Bandung, West Java, Indonesia
}

\begin{abstract}
Hardjonagoro Go Tik Swan was a Javanese of Tionghoa ( Chinese descendent in Indonesia) who was curious about ancient manuscripts, statues, dances, puppets, batik, and art in general. He became a prominent Javanese culture scholar acknowledged by peers in his era. His breakthrough in re-inventing batik while maintaining its classical values has established his creation to be known as modern batik. As a batik artist, Hardjonagoro Go Tik Swan showed a phenomenon where batik dissolves into discourse of life where it integrates and simultaneously follows the development of modern art. This study aims at the analysis of Hardjonagoro Go Tik Swan's batik in the perspective of modern art discourse, focusing the discussion through the aesthetic theory of Feldman (1967) which defines aesthetic value as the ability of an object to experience beauty, and also AM Djelantik's theory (1999) regarding aesthetic elements, which describe that every art object or event contains three basic aspects, namely appearance, content, substance and presentation. This research is expected to reveal the novelty of Hardjonagoro Go Tik Swan's practice of making batik through the discourse of modern art.
\end{abstract}

Keywords: Modern Batik, Aesthetics, Hardjonagoro Go Tik Swan

DOI: $10.7176 / \mathrm{ADS} / 86-03$

Publication date:October $31^{\text {st }} 2020$

\section{Introduction}

Batik has a high artistic value and has become a part of Indonesian culture (especially Javanese). Aside from having very diverse traditional motif, this distinctive attribute emerges from its profound philosophy of archipelago life. Javanese people has been accustomed to batik since the $14^{\text {th }}$ century, during Majapahit Empire era, when it was first introduced originating from India, along with the arrival of Hindu culture in the archipelago, which established the lineage of Hindu Kingdom in the archipelago. Pararaton Ancient Script mentioning the existence of batik as clothing material prominently indicates Hindu-Buddha era batik development during those times. It even mentions motifs such as gringsing and ceplok as types of batik ornament. Statues from this era also show carvings of batik with geometric motifs on their clothes. These were the times where batik flourished along with the reign of Majapahit and Pajajaran Kingdoms(“http://yayasanbatikindonesia.id/id/ragam-hias-batik/," 2020).

Batik motif was found inscribed and painted on palm leaves originating from $17^{\text {th }}$ century. During those times, the motifs were dominated by flora and fauna combined with abstracts in the form of clouds, temple reliefs and wayang beber, etc. The way they write and paint on materials then fashioned into garment thus gave rise to the art of batik. In order to produce batik, one needed an expertise, experience, and it takes time. It was also costly. Due to this nature, batik became the attire to use in palace environment. This situation even lasted until mid $19^{\text {th }}$ century during early days of Surakarta and Yogyakarta Kingdom.

Chris Barker stated that objects are understood as studies of culture through the meaningful practices of their representations (Barker, 2016). Understanding batik as a cultural work, initially, batik appeared to bear only sacral value, because it was used/worn to fit philosophical values of certain types of batik to the ceremonial events and status of the wearer. Then batik began to gain value as merely fit to occasion attire. The sacral and profane values of batik, the grouping of categories based on the appearance of variations in motifs and colors in batik; classic batik, standard batik, and others; all of them can be described as the essence of batik in the language of culture. With its development, not only batik can serve as a language of culture, but can also be interpreted as the language of art, an expression of beauty by the maker.

\section{Overview of Hardjonagoro Go Tik Swan Batik}

Hardjonagoro Go Tik Swan (1931-2008) - a Chinese who was born in Surakarta, Central Java, Indonesia, and raised in a Javanese culture environment - was a collector, designer and thinker of Indonesian arts and culture. In the 1950s, the first President of the Republic of Indonesia, Ir. Soekarno, had the idea to make batik that was not characterized by certain regionalities, a kind that that reflects the diversity of Indonesian society and he gave his mandate to Hardjonagoro Go Tik Swan to create this batik. . The idea that came to Hardjonagoro Go Tik Swan's mind at that time was to essentially combine Surakarta/Yogyakarta Batik with coastal batik. This batik is characterized by a variety of colors, not limited to sogan colors. In his batik, he combines a variety of motifs/patterns from several regions, so that previously unknown rare/traditional batik patterns can be explored and developed. Batik by Hardjonagoro Go Tik Swan has a fairly rich and distinctive patterns. The patterns are 
not new, classic patterns can still easily be recognized within them. While preserving the classic Javanese character patterns, we can clearly see the influence of modern art elements in his batik. This modern influence likely happened formally and informally. Formal influence can occur through social interaction between Hardjonagoro Go Tik Swan and his extensive, multi-ethnic, multi-national associations and various groups who bring insight into the concept of western art.

In Hardjonagoro Go Tik Swan's autobiographical book as told by Rustopo, he conveyed the following statements about the patterns in his batik (Rustopo, 2008);

"I still maintain traditional patterns. I use the technique of coloring the North Coast (with various bright colors) and the South Coast (natural colors soga)"

During its development, Hardjonagoro Go Tik Swan's batik was divided into three periods:

First, Indonesian Batik era (1956-1966); The batik produced in this era is a "new style of batik" (the name given by President Soekarno for the Hardjonagoro Go Tik Swan batik). This batik is characterized by a variety of batik colors (multi-colored), not limited to sogan colors. Many motifs in this era depict birds or flowers. Second, the era of classical batik composition (1970s); in this era Hardjonagoro Go Tik Swan devoted himself to the Surakarta Kasunanan Palace. The batik developed during this time was the classic batik already existed in the palace, Hardjonagoro Go Tik Swan only composed it by adding isen-isen or changing the background. Third, Combination era (2000); in this era, Hardjonagoro Go Tik Swan began to apply the plangkat system in making batik. This combination batik composition is $70 \%$ written and $30 \%$ is stamped.

Based on the facts above, we can see why Hardjonagoro Go Tik Swan batik's creative endeavor is an important and interesting object to study.

\section{Purpose}

The modern art discourse in batik Harjonagoro Go Tik Swan as innovative design through multi-aesthetic arrangement of visual element includes the plotting of fabric, the placement of the main motif, the supporting motif and the background motif (isen-isen).

\section{Method}

This is a research on batik as a cultural work and a multi-aesthetic work which systematic discussion begins with an aesthetic analysis where the form, style and meaning of its aesthetic function of batik in the framework of fine arts science is discussed.

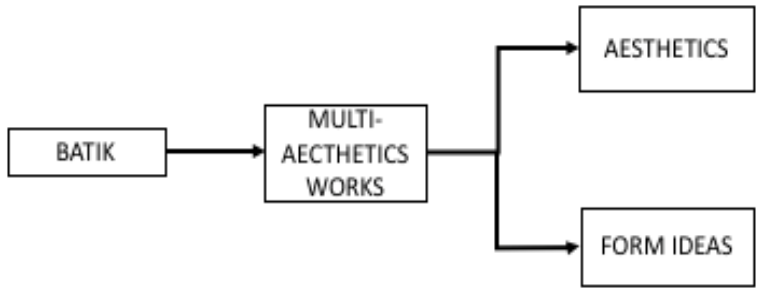

Figure 1. Method Scheme

The discussion is directed to the focus of this research, which is the modern style in batik. Analysis through the aesthetic theory of Edmund Burke Feldman (Feldman, 1967) which defines aesthetic value as the ability of an object to experience beauty. In addition, it is also analyzed according to the theory presented by AM Djelantik (Djelantik, 1999) regarding aesthetic elements, that every art object or event contains three basic aspects, i.e. appearance, content/substance and presentation. In works-of-art there are forms and structures. There are three basic aesthetic elements in the structure of every work of art that play a role in creating a sense of beauty in the observer, namely: wholeness and unity, predominance or emphasis, and balance.

\section{Literature Review}

According to Sewan Susanto in his book "Technique of Making Traditional Batik and Modern Batik", modern Batik is all types of batik which motifs and styles are different than classic batik. In classical batik, the arrangement of the motifs is bound by certain rules and by certain isen-isen, the background pattern. If you deviate from the ties or rules that have become a tradition, it is said to deviate from batik, which means deviating from classic batik. While the beauty of classic batik lies in the perfect arrangement of motifs, colors, patterns and manufacturing techniques, many of which apply slitiran motifs in the form of animals, parang, clouds, water, plants, volcanoes and so on (Hamzuri, 1981). In classical batik, the arrangement of the motifs is always bound by a certain bond and certain isen-isen, if it deviates from the ties that have become a tradition, it is said to 
deviate from the traditional ties of classical batik (Susanto, 2018).

According to Bambang Utoro and Kuwat, in their book entitled "Batik Patterns and Coloring" the meaning of the word modern is today or the present. So modern batik motifs are batik motifs of today. Modern batik is mostly made by artists, as well as batik designers. Modern batik is made not for use, but for decoration or wall decoration purposes. The motifs made in modern batik are very independent depending on the artist or designer. Indeed, batik is made with techniques such as painting, and is tied to a commonly used tool, namely canting. The implementation is exactly like painting, only the technique and coloring process is the same as the batik process (Utoro, 1979).

Starting in the year of 1950s, there was an effort to change and renew classical batik motifs and styles, and it turned out that this change received a response from several artists and was accepted by the community. In the following years, prominent dynamic batik figures and artists took part in the development of this non-classical or modern batik. Several types of batik emerged in this modern batik, including: dynamic abstract style, for example depicting flying birds, fighting cocks, jumping arrows, flower arrangements, etc. Combining Style, which is processing and combining motifs from various regions into a beautiful series. Painting Style, which depicts something similar to a painting, such as landscapes, building shapes and so on, is filled with neatly arranged isen to produce a beautiful artistic result (Susanto, 2018).

We can conclude that modern batik is a variation in the development of batik, with motifs that can still be distinguished into its elements, which ornaments are no longer in the form of traditional but have been modified or changed. So is the coloring, which combines classical and non-classical batik colors.

\section{Discussion}

A wide sheet of batik cloth, contains repetition of motifs that fill the entire batik cloth. Hence it emphasizes the importance of the type and placement of the main motive, the supporting motive and the filler motif (isen-isen). The main motif is usually larger in size compared to other motifs, and is depicted in more detail than the others. The supporting motifs are other smaller motifs and fill in the sections between the main motifs. Meanwhile, isen-isen are motifs that fill the blank spaces between the main motifs and the supporting motifs. The decoration in some coastal batik is a decoration that can be drawn directly on the cloth, directly with the canting. The difference between the palace and the coastal batik basically lies in the coloring, patterns, and motifs related to the function and philosophical background. In terms of patterns, the palace batik (Yogyakarta and Surakarta) is characterized by: (1) stylized forms of the flora and fauna world; (2) the number of isen-isen; (3) the composition is spread out with images of fine and detailed motifs; and (4) the overall arrangement looks full and crowded. As for coastal batik, the characteristics of the pattern are (1) the depiction of flora and fauna tends to be realistic/naturalistic rather than simplified or abstract, and is sometimes combined with geometric patterns; (2) lots of isen-isen; (3) the side uses a fringed composition with a plain background.

In terms of color categorization, according to traditional perception, classical batik is a batik that has been completed after giving soga (brownies) color to the klowongan which is the white batik cloth (mori), with its multi-colored background. The completed Solo Batik, according to Javanese customs, is the formal dress for the reception, not work clothes. As for the Pekalongan (coastal batik central) batik, it is called the kelengan batik which has multi-colored characteristics, according to Surakarta's perception it is a semi-finished or unfinished batik, because the klowongan has not been given soga color, or is still mori (white) in color. Based on visual analysis of batik by Hardjonagoro Go Tik Swan, the finished Surakarta batik and the half-finished Pekalongan batik by Hardjonagoro Go Tik Swan were merged, and a new batik model was born that has developed until now.

\subsection{Multi aesthetics in the work of Hardjonagoro Go Tik Swan}

Based on observations, Hardjonagoro Go Tik Swan batik is a combination of masculine and limited color characteristics of Javanese classic batik such as sogan, black and white combined with the Pekalongan batik color style which has bright and dynamic colors. Apart from applying bright colors, Hardjonagoro Go Tik Swan has also developed batik that remains in the nuances of the classic palace batik.

Go Tik Swan's Hardjonagoro batik works show his consistency with the traditional concept which is the basis of his creation. Thus, no matter how modern the new style of batik is by Hardjonagoro Go Tik Swan, it still manages to preserve its roots, that is Javanese culture. 
Table 1. Multi Aesthetics element in Hardjonagoro Go Tik Swan Batik

\begin{tabular}{|c|c|c|c|c|}
\hline No & $\begin{array}{l}\text { Aesthetics } \\
\text { Element of } \\
\text { Batik } \\
\end{array}$ & $\begin{array}{c}\text { Batik } \\
\text { Surakarta/Yogyakarta }\end{array}$ & Coastal Batik & $\begin{array}{c}\text { Batik Hardjonagoro } \\
\text { Go Tik Swan }\end{array}$ \\
\hline 1. & Batik structure & $\begin{array}{l}\text { repetition of one motif/theme } \\
\text { with small fringe }\end{array}$ & $\begin{array}{c}\text { composition of fringe, } \\
\text { head and plain colored } \\
\text { background }\end{array}$ & $\begin{array}{c}\text { repetition of one } \\
\text { motif/theme without fringe } \\
\text { or head. }\end{array}$ \\
\hline 2. & Form & Long Cloth & Tubular cloth (sarong) & $\begin{array}{l}\text { Long cloth } \\
\end{array}$ \\
\hline 3. & Material & cotton & cotton and silk & cotton \\
\hline 4. & $\begin{array}{c}\text { Structure of } \\
\text { ornament }\end{array}$ & full and repetitive & $\begin{array}{c}\text { plain colored } \\
\text { background, spread or } \\
\text { one panel motif } \\
\end{array}$ & full and spread \\
\hline 5. & Rhythm & regular & dynamic & regular and dynamic \\
\hline 6. & Main ornament & form of the flora and fauna & $\begin{array}{l}\text { realistic / naturalistic } \\
\text { shapes, combined with } \\
\text { geometric motifs }\end{array}$ & $\begin{array}{l}\text { realistic / naturalistic form, } \\
\text { and there is also simplified }\end{array}$ \\
\hline 7. & $\begin{array}{c}\text { Secondary } \\
\text { motif }\end{array}$ & none & none or full & none or full \\
\hline 8. & $\begin{array}{c}\text { background } \\
\text { (Isen-isen) }\end{array}$ & Full & none or full & none or full \\
\hline 9. & $\begin{array}{l}\text { Dots, Line } \\
\text { contour }\end{array}$ & bold & fine and detail & bold, fine and detail \\
\hline 10. & Color & $\begin{array}{l}\text { Indigo, white, black, } \\
\text { brownies }(\operatorname{sog} a)\end{array}$ & $\begin{array}{l}\text { red, turquoise, green, } \\
\text { purple, white, pastel } \\
\text { colors }\end{array}$ & $\begin{array}{l}\text { red, turquoise, green, } \\
\text { purple, white, pastel colors, } \\
\text { brownies }(\operatorname{sog} a)\end{array}$ \\
\hline
\end{tabular}

\subsection{Modern art discourse in batik by Hardjonagoro Go Tik Swan}

The arrangement of visual elements in the Hardjonagoro Go Tik Swan batik are direct presentations that can be sensed visually by the observer. In order to analyze the discourse of modern art in the Hardjonagoro Go Tik Swan batik in this study, several visual element analysis models will be carried out on his batik work. The model for arranging the ornaments variety includes the plotting of fabric, the placement of the main motif, the supporting motif and the background motif (isen-isen).

First, the notably different dimensions of motives that can be captured visually. The different dimensions are captured in large intervals, short long waves that catch the eye, creating contrasts. The combination of contrasts is a composition that is also found in Sawunggaling motif of the Hardjonagoro Go Tik Swan batik, which is a blend of sharply different elements. All the dimensions are very different (large intervals), short wavelengths that are caught by the eye inducing color impressions. When observed further, the contrasting game here serves to stimulate visual beauty, invigorating the design, utilizing contrast as ingredient of composition.

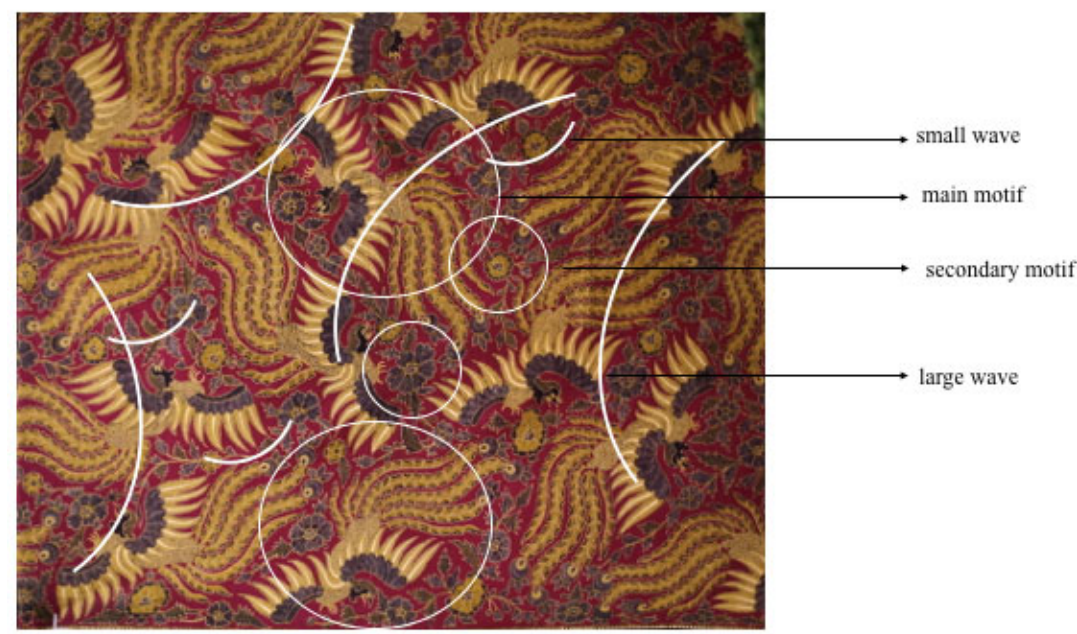

Figure 2. Combination of Contrasting Motive and large small wave in the Sawunggaling Batik MotifIn

Figure 2. it is clear that there is a combination of contrasts between the shapes of the motifs with large and small waves, showing visual beauty and adding to the lively impression of the battle between two roosters. 
In Hardjonagoro Go Tik Swan batik, when analyzed deeper, the aesthetic elements are combined side by side so that certain combinations appear and harmony arises. Harmony here means a combination of different but close elements. The existence of a moderate interval actually creates synchronicity in the overall design which generally has a harmonizing effect.

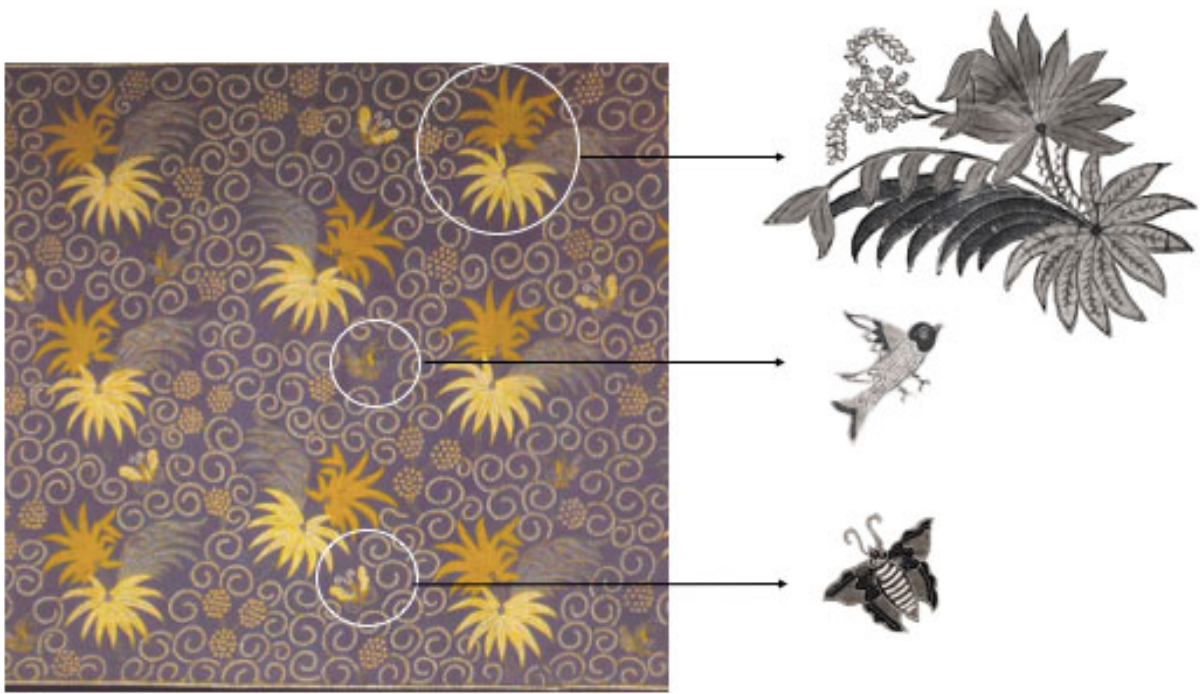

Figure 3. A harmonious combination of themes between coconut leaf, bird and butterfly motifs in the Gedebyah batik motif

Figure 3. shows that in Gedebyah batik, there is a harmony between the elements of the motif of coconut leaves, manggar, birds and butterflies as a unity of plants (coconut) and animals that help pollinate them. To enable the safest possible quality of visual taste is to utilize synchronicity, but its use and excessive repetition will appear monotonous and boring, a little contrast or discordant mix will be interesting, but excessive contrast will appear crowded, scattered and will mess up the design.

In the next section we will analyze the quality of the basic components of the ornament arrangement in the Hardjonagoro Go Tik Swan batik. In that perspective, the arrangement of ornament styles will be examined based on the principles of unity, balance, simplicity, emphasis and proportion.

Unity is the effect achieved in an arrangement or composition between the relations of the supporting elements of the work, so that as a whole it displays the impression of a complete response. In fact, Hardjonagoro Go Tik Swan Batik pays great attention to the integration of aesthetic elements in a motif that also shows its overall ability to guide it. There is a wholeness that can be reached by several events, and a wholeness that is formed because there is a dominant element. In other words, the existence of a dominant element is not intended to intimidate other elements, but without a dominant design or arrangement it becomes imperfect.

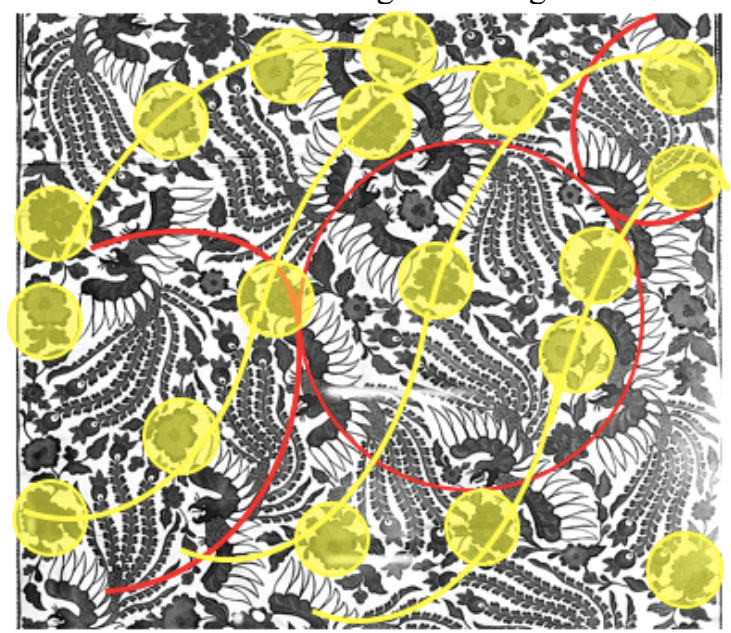

Figure 4. The Unity of Composition Between Elements in the Sawunggaling Motif

Sawunggaling motif as the example above shows how the composition between the two main motifs (rooster) that forms unity, as well as forging unity with the supporting motif (hibiscus) which has also been woven into one unit itself.

In fact, the size, shape, color, and presence of all elements are very much considered and considered in the 
Hardjonagoro Go Tik Swan batik so that it forms a balance. Balance in arrangement is the state of equilibrium between the forces that are most opposite each other and give rise to a balanced impression visually or in the intensity of work. According to the theory of formal equilibrium design is the balance on two opposing sides of one axis. Most formal equilibrium is precisely symmetrical or replicated reversed on the side (Tabrani, 2012).

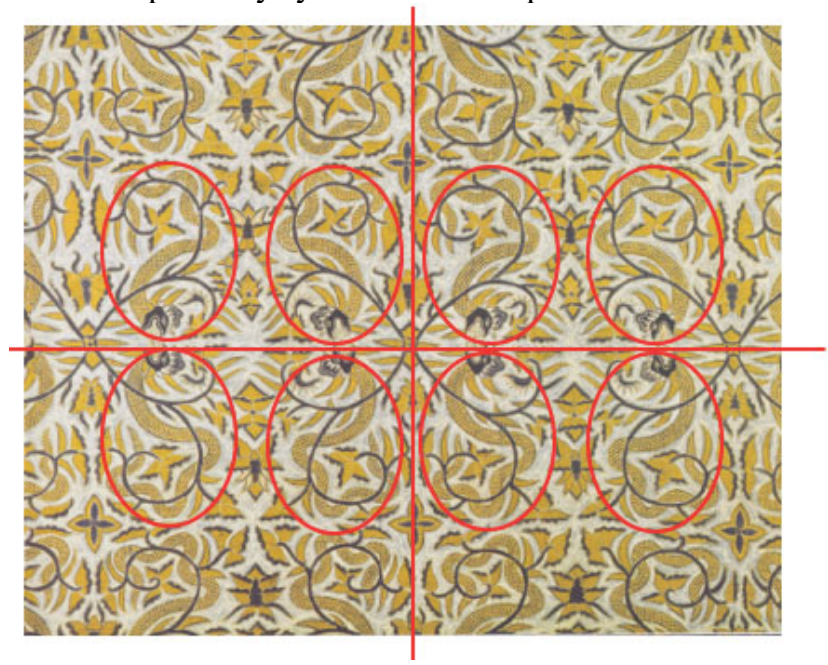

Figure 5. Balance due to the size and number of motifs (as if like mirrors) in batik Hardjonagoro Go Tik Swan

The formal balance is static and symmetrical right-left and top-bottom as if looking into a mirror as seen in the Gedebyah batik motif. In fact, Hardjonagoro Go Tik Swan closely scrutinize the integration of visual elements to allure a sense of beauty of modern art in his batik.

\section{Conclusion}

When analyzed based upon principles of unity, balance, simplicity, accentuation and proportion, the arrangement of basic components in Hardjonagoro Go Tik Swan decorative styles follow the discourse of modern art as an innovative effort in batik designs. It can be concluded that modern batik is a variation in the development of batik, with motifs that can still be distinguished into its elements. The ornaments in it are no longer traditional but have been modified or changed. The visual structure in Hardjonagoro Go Tik Swan batik shows that in an object a curved posture is seen, depicted in detail, and added striking colors. Objects are depicted in a beautiful, beautiful, handsome, big and colorful. The relation between visual element in Harjonagoro Go Tik Swan batik on the aspect of form, the aesthetic concept emphasizes visual attractiveness through the depiction of naturalist, highly ornamental motifs, more dynamic posture and larger size compared to classical batik. In shaping the character of the motive, it also makes use of rhythm and intensity of lines and dots. The visual structure is made more expressive. In showing its multi-aesthetic expression as batik that is not characterized by any particular regionalism, elements of modern batik by Hardjonagoro Go Tik Swan in the form of an amalgamation of classic batik styles and acculturation with coastal colors show a portrait of post-independence change in Indonesian society, which is no longer about ethnicity but respecting cultural diversity.

\section{References}

Barker, C. (2016). Cultural Studies, Teori \& Praktik (10th ed.). Bantul: Kreasi Wacana.

Djelantik, A. (1999). Estetika. Bandung: Masyarakat seni pertunjukan indonesia.

Feldman, E. B. (1967). Art as Image and Idea. California: Prentice-Hall.

Hamzuri. (1981). Batik Klasik. Jakarta: Djambatan.

http://yayasanbatikindonesia.id/id/ragam-hias-batik/. (2020).

Rustopo. (2008). Jawa Sejati: Otobiografi Go Tik Swan Hardjonagoro. Yogyakarta: Ombak.

Susanto, S. S. (2018). Seni Kerajinan Batik Indonesia, Balai Penelitian Batik dan Kerajinan. Yogjakarta: Penerbit Andi.

Tabrani, P. (2012). Bahasa Rupa. Bandung: Kelir.

Utoro, B. (1979). Pola-Pola Batik dan Pewarnaan. Jakarta: Direktorat Pendidikan Menengah Kejuruan. 